\title{
Pengaruh Model Pembelajaran Sains Teknologi Masyarakat (STM) dalam Pembelajaran Biologi Bermuatan Karakter terhadap Keterampilan Berpikir Kritis dan Kemampuan Pemecahan Masalah
}

\author{
Eka Dora Riani ${ }^{1}$, I Wayan Sadia ${ }^{2}$, Ida Bagus Jelantik Swasta ${ }^{3}$ \\ ${ }^{123}$ Program Studi Pendidikan IPA, Program Pascasarjana \\ Universitas Pendidikan Ganesha, Singaraja, Indonesia \\ e-mail: dora.riani@pasca.undiksha.ac.id ${ }^{1}$, wayan.sadiai@pasca.undiksha.ac.id ${ }^{2}$, \\ bagus jelantiki@pasca.undiksha.ac.id ${ }^{3}$
}

\begin{abstract}
Abstrak
Penelitian ini bertujuan untuk mengetahui perbedaan keterampilan berpikir kritis dan kemampuan pemecahan masalah antara kelompok siswa yang belajar dengan model pembelajaran STM dalam pembelajaran biologi bermuatan karakter dan model pembelajaran DI. Populasi dalam penelitian ini adalah siswa kelas X SMAN 1 Banjarangkan tahun pelajaran 2013/2014. Sampel yang digunakan sebanyak 82 siswa. Penelitian ini tergolong eksperimen semu dengan rancangan pretest-posttest nonequivalent control group design. Data dianalisis dengan menggunakan statistik deskriptif dan MANOVA satu jalur dan dilanjutkan dengan uji LSD pada taraf signifikansi 5\%. Hasil penelitian menunjukkan bahwa: (1) terdapat perbedaan keterampilan berpikir kritis dan kemampuan pemecahan masalah antara kelompok siswa yang belajar dengan MP.STM dalam pembelajaran biologi bermuatan karakter dan MP.DI (F= 76,528; $\mathrm{p}<0,05)$, (2) terdapat perbedaan keterampilan berpikir kritis antara kelompok siswa yang belajar dengan MP.STM dalam pembelajaran biologi bermuatan karakter dan MP.DI ( $\mathrm{F}=$ $3,336 ; p<0,05)$, (3) terdapat perbedaan kemampuan pemecahan masalahan antara kelompok siswa yang belajar dengan MP.STM dalam pembelajaran biologi bermuatan karakter dan MP.DI $(F=146,110 ; p<0,05)$. Hasil uji lanjut dengan LSD terlihat MP.STM lebih baik dengan MP.DI dalam keterampilan berpikir kritis dan kemampuan pemecahan masalah.
\end{abstract}

Kata kunci: Sains Teknologi Masyarakat, Berpikir Kritis, Kemampuan Pemecahan Masalah

\begin{abstract}
The aims of this research is to find out the difference of critical thinking and problem solving abillity between the group of students learn with science learning model in Biology that contains character and the group of students learn with DI model. The population of this research was the tenth grade students of SMAN 1 Banjarangkan in the academic year 2013/2014. The sample of this research was 82 students. This research is categorized quasiexperimental research design with pretest-posttest nonequivalent control group. The data was analyzed by using descriptive statistic, one way Manova and LSD test. The results of this research showed that (1) there was difference of critical thinking and problem solving learning between the group of students learn with society science learning model in Biology that contains character and the group of students learn with $D I$ model $(F=76,528 ; p<0,05)$, (2) there was difference of critical thinking between the group of students learn with society science learning model in Biology that contains character and the group of students learn with DI model ( $F=$ $3,336 ; p<0,05)$, (3) there was difference of problem solving learning between the group of students learn with society science learning model in Biology that contains character and the group of students learn with DI model $(F=146,110 ; p<0,05)$. Moreover, the result of this research with LSD shown that society science learning model is better than DI learning model in critical thinking and problem solving abillity.
\end{abstract}

Keywords: Society Science Technology Learning Model, Critical Thinking, Problem Solving 


\section{Pendahuluan}

Pendidikan adalah suatu proses memperoleh pengetahuan dan keterampilan yang bermanfaat dalam menghadapi era globalisasi dan perkembangan IImu Pengetahuan dan Teknologi (IPTEK). Salah satu amanat UUD 1945 adalah mencerdaskan kehidupan bangsa dan cara yang paling tepat untuk meningkatkan kualitas manusia adalah melalui pendidikan.

Dalam upaya pencapaian tujuan pendidikan nasional dan memenuhi tuntutan dalam IPTEK, pemerintah telah melakukan berbagai upaya inovatif. Namun upaya tersebut belum mampu meningkatkan mutu pendidikan indonesia secara signifikan. Hal ini salah satunya dapat dilihat dari penelitian yang dilakukan oleh The Thrid International Mathematics and Science Study-Repeat (TIMSS-R) yang melaporkan bahwa Indonesia menempati peringkat 32 untuk IPA dari 38 negara yang disurvei di Asia (Wikipedia, 2010). Ini disebabkan, pendidikan di Indonesia selama ini hanya mementingkan perolehan nilai atau hasil akhir saja, tanpa memfokuskan pada pemahaman dan manfaat dari proses pembelajaran tersebut.

Pendidikan merupakan proses pembentukan karakter manusia, sehingga dapat diduga bahwa akar permasalahan kualitas pendidikan yang masih rendah juga terkait dengan keterpurukan jati diri bangsa. Pendidikan yang diterapkan di sekolah-sekolah menuntut untuk memaksimalkan kecakapan dan kemampuan kognisi. Untuk menyeimbangkan kecakapan kognitif diperlukan pendidikan karater.. Pendidikan karakter di institusi-institusi pendidikan belakangan ini mendapat banyak sorotan dari kalangan pemerhati pendidikan baik di mediamassa, seminar dan berbagai kesempatan. Hal ini sehubungan dengan maraknya penyimpangan prilaku yang muncul dimasyarakat seperti korupsi, kekerasan, kejahatan seksual, perusakan, perkelahian massa, etika yang menipis, kurangnya tenggang rasa dan tanggung jawab menjadi konsumsi sehari-hari di mediamassa, yang mengkhawatirkan kondisi ini muncul di lingkungan pelajar, sehingga masalah karakter menjadi masalah moral yang serius di Indonesia. Pembinaan karakter termasuk salah satu bagian penting yang perlu disisipkan dalam materi yang harus diajarkan dan dikuasai serta direalisasikan oleh peserta didik dalam kehidupan sehari-hari.

Sistem pendidikan yang baik diharapkan dapat meningkatkan kualitas sumber daya manusia. Oleh karena itu, pendidikan dewasa ini harus diarahkan pada peningkatan daya saing bangsa agar mampu berkompetisi dalam persaingan global. Hal ini bisa tercapai jika pendidikan di sekolah diarahkan tidak semata-mata pada penguasaan dan pemahaman konsep-konsep ilmiah, tetapi juga pada peningkatan kemampuan pemecahan masalah dan keterampilan beripikir siswa, khususnya keterampilan berpikir tingkat tinggi yaitu keterampilan berpikir kristis (critical thinking skills).

Kemampuan untuk berkompetensi dihasilkan oleh pendidikan yang kondusif bagi lahirnya pribadi-pribadi yang cerdas komprehensif dan kompetitif (Sadia, 2011). Insan yang cerdas komprehensif yaitu insan yang cerdas spiritual, cerdas emosional dan sosial, dan cerdas intelektual serta cerdas kinestika. Sedangkan insan yang kompetitif adalah insan yang berkepribadian unggul dan gandrung akan keunggulan, bersemangat juang tinggi, mandiri, pantang menyerah, inovatif dan menjadi agen perubahan, berorientasi global, pembelajar sepanjang hayat. Untuk membentuk insan yang cerdas, sangat diperlukan insan yang dapat berpikir tingkat tinggi (Sadia, 2011).

Keterampilan berpikir tingkat tinggi, yang dikategorikan menjadi berpikir kritis dan berpikir kreatif. Berpikir kritis (critical thinking) merupakan topik yang penting dan vital dalam era pendidikan modern (Schafersman, 1991). Johnson (2002) menyatakan bahwa berpikir kritis dapat digunakan sebagai sarana dalam memecahkan masalah, mengambil keputusan, mencari jawaban, memperkaya arti, memenuhi keinginan untuk mengetahui sesuatu. Keterampilan berpikir kritis dapat membantu manusia membuat keputusan yang tepat berdasarkan usaha yang cermat, sistematis, logis, dan mempertimbangkan berbagai sudut pandang. Sadia (2008) mengungkapkan bahwa tujuan khusus pembelajaran berpikir kritis dalam pendidikan sains maupun disiplin yang lain adalah untuk meningkatkan keterampilan berpikir siswa dan sekaligus menyiapkan mereka agar sukses dalam menjalani kehidupannya.

Kemampuan pemecahan masalah (problem solving) adalah kemampuan individu dalam menggunakan proses berpikirnya untuk memecahkan permasalahan melalui pengumpulan fakta-fakta, analisis informasi, menyusun berbagai alternatif pemecahan, dan memilih pemecahan masalah yang paling efektif (Yamin, 2008). Kemampuan memecahkan masalah, yang banyak memberdayakan berpikir reflektif, kritis dan analitis dituntut dimiliki para siswa SMA di era pengetahuan. Kemampuan-kemampuan ini diyakini mampu membantu siswa membuat keputusan yang tepat, cermat, sistematis, logis dan mempertimbangkan berbagai 
sudut pandang. Sebaliknya kurangnya kemampuan-kemampuan ini mengakibatkan siswa pada kebiasaan melakukan berbagai kegiatan tanpa mengetahui tujuan dan alasan melakukannya (Paidi, 2008). Perlunya siswa SMA mempunyai kemampuan berpikir tingkat tinggi dan pemecahan masalah, secara eksplisit telah dirumuskan dalam Permen 22, tahun 2006 tentang standar isi KTSP untuk mata pelajaran biologi SMA/MA (Depdiknas, 2006).

Dari permasalahan di atas, keterampilan berpikir kritis dan kemampuan memecahkan masalah dapat ditumbuhkan melalui proses pembelajaran yang memberikan kesempatan kepada siswa untuk berperan secara aktif untuk mengkontruksi pengetahuannya sesuai dengan pandangan kontruktivisme. Salah satu model pembelajaran inovatif yang dapat diterapkan adalah model pembelajaran Sains-Teknologi-Masyarakat (STM), untuk meningkatkan keterampilan berpikir kritis dan kemampuan memecahkan masalah pada siswa. Rustum Roy (dalam Sadia, 2009) menyatakan bahwa model pembelajaran STM dalam pembelajaran sains merupakan "perekat" yang mempersatukan sains, teknologi, dan masyarakat. Isu-isu sosial dan teknologi di masyarakat merupakan karakteristik kunci dari model pembelajaran STM. Melalui model pembelajaran STM, para siswa belajar sains dalam konteks pengalaman nyata, yang mencakup penerapan sains dan teknologi. Model pembelajaran STM memiliki ciri antara lain: 1) difokuskan pada isu-isu sosial dan teknologi di masyarakat yang terkait dengan konsep dan prinsip sains yang akan diajarkan, 2) diarahkan pada peningkatan pengetahuan dan ketrampilan siswa dalam membuat keputusan berdasarkan informasi ilmiah, 3) tanggap terhadap karir pada masa depan, dan 4) evaluasi belajar ditekankan pada kemampuan siswa dalam memperoleh dan menggunakan informasi ilmiah untuk memecahkan masalah. Keempat ciri model STM ini direalisasikan melalui empat fase dalam model pembelajaran STM yaitu invitation (brainstorm an issue or topic), exploration, proposing explanations and solutions, dan taking action (Dass, 2005).

Berdasarkan latar belakang masalah tersebut, penelitian ini memusatkan perhatian untuk menjawab tiga pertanyaan penelitian. (1) Apakah terdapat perbedaan keterampilan berpikir kritis dan kemampuan pemecahan masalah antara kelompok siswa yang belajar dengan model pembelajaran STM dalam pembelajaran biologi bermuatan karakter dan model pembelajaran DI? (2) Apakah terdapat perbedaan keterampilan berpikir kritis antara kelompok siswa yang belajar dengan model pembelajaran STM dalam pembelajaran biologi bermuatan karakter dan model pembelajaran DI? (3) Apakah terdapat perbedaan kemampuan pemecahan masalah antara kelompok siswa yang belajar dengan model pembelajaran STM dalam pembelajaran biologi bermuatan karakter dan model pembelajaran DI?

\section{Metode}

Jenis penelitian yang dilaksanakan adalah eksperimen semu (Quasi experimental) karena tidak semua variabel dan kondisi eksperimen dapat diatur dan dikontrol secara ketat (Nazir, 2003) dengan desain penelitian "nonequivalent pretest-postttest control group design". (Wiersma, 1990). Populasi penelitian ini adalah siswa kelas X semester II SMA Negeri 1 Banjarangkan tahun pelajaran 2013/2014. Pengambilan sampel dilakukan dengan teknik simple random sampling (Sugiyono, 2008). Berdasarkan hasil undian secara random diperoleh kelas $X_{1}$ dan $X_{3}$ sebagai kelompok eksperimen, sedangkan kelas $X_{4}$ dan $X_{6}$ sebagai kelompok kontrol.

Variabel terikat dalam penelitian ini adalah keterampilan berpikir kritis dan kemampuan pemecahan masalah. Variabel bebas terdiri dari model pembelajaran sains teknologi masyarakat (MP.STM) pada kelompok eksperimen dan model pembelajaran langsung atau direct intruction (MP.DI) pada kelompok kontrol. Data yang dikumpulkan dalam penelitian ini adalah keterampilan berpikir kritis dan kemampuan pemecahan masalah siswa yang diukur dengan tes keterampilan berpikir kritis dan tes kemampuan pemecahan masalah. Tes keterampilan berpikir kritis berbentuk objektif yang mengacu pada indikator yang dikembangkan oleh tim peneliti Delphi seperti yang tercantum dalam The California Academic Press (1990) yang terdiri dari 29 butir soal dengan indeks konsistensi internal butir $(r)$ bergerak dari 0,493 s.d 0,08 dan indeks reliabelitas tes Alpha Cronbach sebesar 0,800 dengan klasifikasi sangat tinggi. Aspek-aspek yang diukur dalam keterampilan berpikir kritis meliputi interpretasi, analisis, evaluasi, inferensi, dan eksplanasi Kriteria penilaian tes keterampilan berpikir kritis dengan menggunakan rubrik penilaian skor $=1$ apabila menjawab dengan benar dan skor $=0$ apabila tidak menjawab atau jawaban salah. Tes kemampuan pemecahan masalah berbentuk tes uraian yang terdiri dari 8 butir soal dengan indeks konsistensi internal butir $(r)$ bergerak dari 0,709 s.d 0,421 dan indeks reliabelitas tes Alpha Cronbach sebesar 0,824 dengan klasifikasi 
sangat tinggi. Aspek-aspek yang diukur dalam kemampuan pemecahan masalah meliputi (1) mengidentifikasi masalah, (2) merumuskan atau menganalisis masalah; (3) menemukan alternatif-alternatif solusi, (4) memilih alternatif solusi atau solusi terbaik, (5) kelancaran memecahkan masalah, (6) kualitas hasil pemecahan masalah. Setiap soal memiliki rentangan skor 0-4, maka skor minimal untuk soal kemampuan pemecahan masalah adalah 0 sedangkan skor maksimal adalah 24 dengan total skor maksimal ideal adalah 192.

Data dianalisis secara deskriptif dan Multivariat Analysis of Varian (MANOVA). Analisis deskriptif digunakan untuk mendeskripsikan skor rata-rata dan simpangan baku keterampilan berpikir kritis dan kemampuan pemecahan masalah siswa. Pengujian hipotesis penelitian digunakan MANOVA satu jalur. Sebelum pengujian hipotesis dilakukan uji normalitas sebaran data dengan menggunakan statistik Kolmogorov-Smirnov, uji homogenitas varian antar kelompok menggunakan Levene's Test of Equality of Error Variance, uji homogenitas matrik varian menggunakan uji Box's $M$, dan uji kolinieritas variabel terikat menggunakan uji korelasi Product Moment. Uji komparasi signifikansi skor rata-rata menggunakan Least Significant Difference (LSD) (Montgomery, 1996). Semua pengujian hipotesis dilakukan pada taraf signifikansi 0,05 .

Untuk penilaian karakter dllakukan melalui tiga fase penilaian, fase I (pertemuan ke-1), fase II (pertemuan ke-4) dan fase III (pertemuan ke-7) dengan rubrik penilaian adalah: Skor $=1$, Apabila belum tampak (apabila peserta didik belum memperlihatkan adanya tanda-tanda awal perilaku/karakter yang dinyatakan dalam indikator). Skor $=2$, Apabila mulai tampak (apabila peserta didik sudah memperlihatkan adanya tanda-tanda awal perilaku/karakter yang dinyatakan dalam indikator tetapi masih sedikit dan belum ajeg/konsisten). Skor $=3$, Apabila mulai berkembang (apabila peserta didik memperlihatkan adanya tanda-tanda awal perilaku/karakter yang dinyatakan dalam indikator yang cukup sering dan mulai ajeg/konsisten). Skor = 4, Apabila membudaya (apabila peserta didik memperlihatkan adanya tanda-tanda awal perilaku/karakter yang dinyatakan dalam indikator yang secara terus menerus dan mulai ajeg/konsisten).

\section{Hasil dan Pembahasan}

\section{Deskripsi Umum Hasil Penelitian}

Deskripsi umum hasil penelitian yang dipaparkan adalah deskripsi skor keterampilan berpikir kritis dan kemampuan pemecahan masalah siswa disajikan pada Tabel 1 dan grafik perbandingan gain score untuk tiap model pembelajaran disajikan pada Gambar 1.

Tabel 1. Deskripsi Skor Keterampilan

\begin{tabular}{|c|c|c|c|c|c|c|c|}
\hline \multirow{2}{*}{\multicolumn{2}{|c|}{ Deskripsi Statistik }} & \multicolumn{3}{|c|}{ MP. STM } & \multicolumn{3}{|c|}{ MP.DI } \\
\hline & & Pre-test & $\begin{array}{c}\text { Post- } \\
\text { test }\end{array}$ & $\begin{array}{l}\text { Gain } \\
\text { skor }\end{array}$ & $\begin{array}{l}\text { Pre- } \\
\text { test }\end{array}$ & $\begin{array}{c}\text { Post- } \\
\text { test }\end{array}$ & $\begin{array}{l}\text { Gain } \\
\text { skor }\end{array}$ \\
\hline \multirow{7}{*}{$\begin{array}{l}\text { Keterampilan } \\
\text { Berpikir Kritis }\end{array}$} & Rata-rata & 35,41 & 56,35 & 0,319 & 32,21 & 50,97 & 0,27 \\
\hline & Median & 37,93 & 55,17 & 0,32 & 31,03 & 51,72 & 0,29 \\
\hline & Varian & 96,34 & 69,321 & 0,014 & 85,97 & 76,99 & 0,014 \\
\hline & $\begin{array}{l}\text { Simpangan } \\
\text { Baku }\end{array}$ & 9,82 & 8,32595 & 0,118 & 9,27 & 8,78 & 0,117 \\
\hline & Minimum & 17,24 & 41,38 & 0,08 & 17,24 & 24,14 & 0,00 \\
\hline & Maksimum & 58,62 & 79,31 & 0,60 & 58,62 & 65,52 & 0,48 \\
\hline & Rentangan & 41,38 & 37,93 & 0,52 & 41,38 & 41,38 & 0,48 \\
\hline \multirow{7}{*}{$\begin{array}{c}\text { Kemampuan } \\
\text { Pemecahan } \\
\text { Masalah }\end{array}$} & Rata-rata & 40,28 & 75,33 & 0,581 & 41,46 & 60,65 & 0,32 \\
\hline & Median & 37,50 & 77,08 & 0,57 & 39,06 & 60,94 & 0,32 \\
\hline & Varian & 106,98 & 34,96 & 0,008 & 54,81 & 17,51 & 0,011 \\
\hline & $\begin{array}{l}\text { Simpangan } \\
\text { Baku }\end{array}$ & 10,34316 & 5,91295 & 0,091 & 7,40 & 4,1843 & 0,10 \\
\hline & Minimum & 25,52 & 60,94 & 0,41 & 25,00 & 53,65 & 0,06 \\
\hline & Maksimum & 67,19 & 84,38 & 0,74 & 59,38 & 68,75 & 0,56 \\
\hline & Rentangan & 41,67 & 23,44 & 0,33 & 34,38 & 15,10 & 0,50 \\
\hline
\end{tabular}

Keterangan: MP.STM adalah Model Pembelajaran Sains Teknologi Masyarakat MP.DI adalah Model Pembelajaran Langsung atau Direct Intruction 


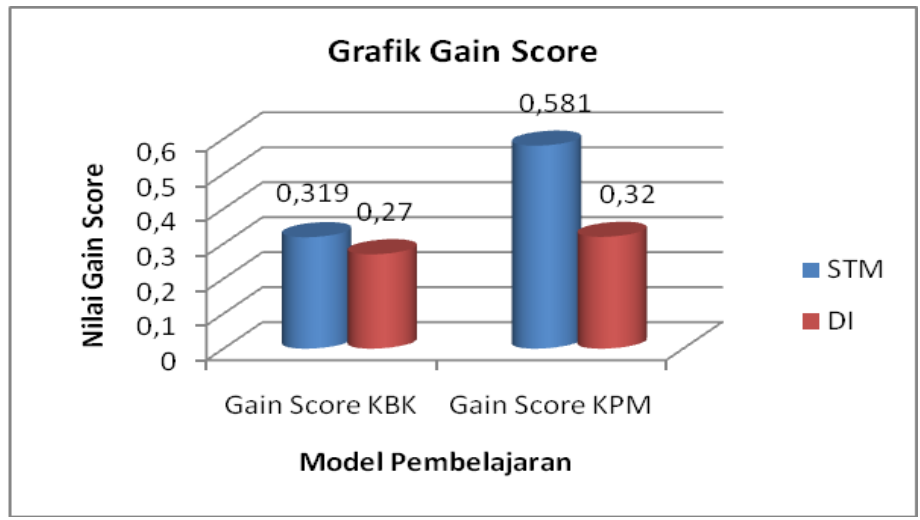

Gambar 1. Grafik Gain Score

Pada Tabel 1 dan gambar 1 tampak bahwa setelah perlakuan kelompok MP.STM menunjukkan pencapaian keterampilan berpikir kritis dan kemampuan pemecahan masalah lebih baik dibandingkan dengan kelompok MP.DI.Hal terlihat dari skor rata-rata keterampilan berpikir kritis pada MP.STM untuk pre-tes 35,41 katagori sangat kurang, rata-rata post 56,35 katagori cukup dan gain skor 0,319 katagori sedang,untuk kemampuan pemecahan masalah skor rata-rata pre-test 40,28 katagori kurang, rata-rata post test 75,33 katagori baik dan gain skor 0,581 katagori sedang. Untuk MP.DI skor rata-rata keterampilan berpikir kritis pada MP.STM untuk pre-tes 32,21 katagori sangat kurang, rata-rata post 50,97 katagori kurang dan gain skor 0,27 katagori rendah, untuk kemampuan pemecahan masalah skor rata-rata pre-test 41,46 katagori kurang, rata-rata post test 60,65 katagori cukup dan gain skor 0,32 katagori sedang.

\section{Deskripsi Pendidikan Karakter}

Adapun deskripsi tentang penilaian karakter pada kelompok MP.STM dan MP.DI dapat dilihat pada Tabel 2.

Tabel 2. Deskripsi Penilaian Karakter Kelompok MP.STM dan MP.DI

\begin{tabular}{|c|c|c|c|c|c|c|c|}
\hline \multirow{2}{*}{ No } & \multirow{2}{*}{ Karakter } & \multicolumn{3}{|c|}{ Kelompok MP.STM } & \multicolumn{3}{|c|}{ Kelompok MP.DI } \\
\hline & & Fase I & Fase II & Fase III & Fase I & Fase II & Fase III \\
\hline 1 & Kejujuran & $\begin{array}{l}\text { Belum } \\
\text { tampa } \\
\mathrm{k}\end{array}$ & $\begin{array}{l}\text { Mulai } \\
\text { tampak }\end{array}$ & $\begin{array}{l}\text { Berkemban } \\
\mathrm{g}\end{array}$ & $\begin{array}{l}\text { Belum } \\
\text { tampa } \\
\mathrm{k}\end{array}$ & $\begin{array}{l}\text { Belum } \\
\text { tampak }\end{array}$ & $\begin{array}{l}\text { Mulai } \\
\text { tampak }\end{array}$ \\
\hline 2 & $\begin{array}{l}\text { Tanggung } \\
\text { jawab }\end{array}$ & $\begin{array}{l}\text { Belum } \\
\text { tampa } \\
\mathrm{k}\end{array}$ & $\begin{array}{l}\text { Mulai } \\
\text { tampak }\end{array}$ & $\begin{array}{l}\text { Berkemban } \\
\mathrm{g}\end{array}$ & $\begin{array}{l}\text { Belum } \\
\text { tampa } \\
\mathrm{k}\end{array}$ & $\begin{array}{l}\text { Belum } \\
\text { tampak }\end{array}$ & $\begin{array}{l}\text { Mulai } \\
\text { tampak }\end{array}$ \\
\hline 3 & Disiplin & $\begin{array}{l}\text { Belum } \\
\text { tampa } \\
\mathrm{k}\end{array}$ & $\begin{array}{l}\text { Mulai } \\
\text { tampak }\end{array}$ & $\begin{array}{l}\text { Berkemban } \\
\mathrm{g}\end{array}$ & $\begin{array}{l}\text { Belum } \\
\text { tampa } \\
\mathrm{k}\end{array}$ & $\begin{array}{l}\text { Belum } \\
\text { tampak }\end{array}$ & $\begin{array}{l}\text { Mulai } \\
\text { tampak }\end{array}$ \\
\hline 4 & Kerja sama & $\begin{array}{l}\text { Mulai } \\
\text { tampa } \\
\mathrm{k}\end{array}$ & berkembang & $\begin{array}{l}\text { Membuday } \\
\text { a }\end{array}$ & $\begin{array}{l}\text { Belum } \\
\text { tampa } \\
\mathrm{k}\end{array}$ & $\begin{array}{l}\text { Belum } \\
\text { Tampak }\end{array}$ & $\begin{array}{l}\text { Mulai } \\
\text { Tampak }\end{array}$ \\
\hline 5 & Toleransi & $\begin{array}{l}\text { Mulai } \\
\text { tampa } \\
\mathrm{k}\end{array}$ & berkembang & $\begin{array}{l}\text { Membuday } \\
\text { a }\end{array}$ & $\begin{array}{l}\text { Belum } \\
\text { tampa } \\
\mathrm{k}\end{array}$ & $\begin{array}{l}\text { Belum } \\
\text { Tampak }\end{array}$ & $\begin{array}{l}\text { Mulai } \\
\text { Tampak }\end{array}$ \\
\hline 6 & $\begin{array}{l}\text { Rasa ingin } \\
\text { tahu }\end{array}$ & $\begin{array}{l}\text { Belum } \\
\text { tampa } \\
\mathrm{k}\end{array}$ & berkembang & $\begin{array}{l}\text { Membuday } \\
\text { a }\end{array}$ & $\begin{array}{l}\text { Belum } \\
\text { tampa } \\
\mathrm{k}\end{array}$ & $\begin{array}{l}\text { Mulai } \\
\text { tampak }\end{array}$ & $\begin{array}{l}\text { berkemb } \\
\text { ang }\end{array}$ \\
\hline
\end{tabular}


IVCEJ, Vol 1 No 1, Tahun 2018

p-ISSN: 2615-4684 e-ISSN: 2615-6938

\begin{tabular}{|c|c|c|c|c|c|c|c|}
\hline & Komunikatif & $\begin{array}{l}\text { Mulai } \\
\text { tampa } \\
\mathrm{k}\end{array}$ & $\begin{array}{l}\text { Berkemban } \\
\mathrm{g}\end{array}$ & $\begin{array}{l}\text { Berkemban } \\
\mathrm{g}\end{array}$ & $\begin{array}{l}\text { Belum } \\
\text { tampa } \\
\mathrm{k}\end{array}$ & $\begin{array}{l}\text { Mulai } \\
\text { tampak }\end{array}$ & $\begin{array}{l}\text { Mulai } \\
\text { tampak }\end{array}$ \\
\hline & $\begin{array}{l}\text { Peduli } \\
\text { lingkungan }\end{array}$ & $\begin{array}{l}\text { Mulai } \\
\text { tampa } \\
\mathrm{k}\end{array}$ & berkembang & $\begin{array}{l}\text { Membuday } \\
\text { a }\end{array}$ & $\begin{array}{l}\text { Belum } \\
\text { tampa } \\
\mathrm{k}\end{array}$ & $\begin{array}{l}\text { Belum } \\
\text { Tampak }\end{array}$ & $\begin{array}{l}\text { Mulai } \\
\text { Tampak }\end{array}$ \\
\hline
\end{tabular}

Berdasarkan deskripsi penilaian karakter pada tabel 4.11 terlihat bahwa pada kelompok MP.STM yang pembelajarannya bermuatan karakter terlihat bahwa karakter kerja sama, toleransi, rasa ingin tahu, dan peduli lingkungan sudah membudaya dan karakter kejujuran, tanggung jawab, disiplin, dan komunikatif sudah mulai berkembang. Hal ini disebabkan karena dalam pembelajaran guru terus menerus mengingatkan dan melatih karakter siswa dengan memasukkan nilai-nilai pendidikan karakter dalam perangkat pembelajaran. Pada karakter kerja sama, toleransi, rasa ingin tahu dan peduli lingkungan sudah membudaya ini dikarenakan siswa terus menerus diingatkan untuk melakukan kerja sama, saling menghargai teman, siswa diingatkan untuk menggali pengetahuan dengan membuat pertanyaan yang mendalam dan meluas kemudian mencari jawaban dari berbagai sumber informasi, dan siswa selalu diingatkan untuk selalu peka dan peduli terhadap lingkungannya. Sedangkan pada MP.DI pada pembelajarannya tidak bermuatan karakter terlihat bahwa karakter kerja sama, toleransi, kejujuran, tanggung jawab, disiplin, komunikatif, mulai tampak dan karakter peduli lingkungan berkembang. Ini berarti bahwa pendidikan karakter sangat penting disisipkan pada materi pelajaran untuk menumbuhkan karakter-karakter yang baik pada siswa.

\section{Pengujian Hipotesis}

Hasil pengujian normalitas data menggunakan statistik Kolmogiorov-Smirnov menunjukkan bahwa nilai-nilai statistik yang diperoleh memiliki angka signifikansi lebih besar dari 0,05 . Hal ini menunjukkan bahwa sebaran data keterampilan berpikir kritis dan kemampuan pemecahan masalah siswa berdistribusi normal. Hasil pengujian homogenitas varian mengunakan Levene's Test of Equality of Error Variances untuk kelompok model pembelajaran menunjukkan angka-angka signifikansi statistik Levene lebih besar dari 0,05. Hal ini menunjukkan bahwa varian antar model pembelajaran adalah homogen. Hasil pengujian homogenitas matrik varian menggunakan uji Box's $M$ menunjukkan bahwa Box's $M$ memiliki nilai 0,891 dengan signifikansi sebesar 0,833 dan lebih besar dari 0,05. Hal ini menunjukkan bahwa matriks varian variabel terikat adalah sama. Hasil pengujian kolinieritas antar variabel terikat menggunakan korelasi Product Moment menunjukkan bahwa harga $r_{\text {hitung }}$ sebesar 0,106 dan Sig.(2-tailed) sebesar 0,044. Karena $\mathrm{r}_{\text {hitung }}<0,8$ dan Sig. (2-tailed) $<0,05$, dapat disimpulkan bahwa variabel keterampilan berpikir kritis dan kemampuan pemecahan masalah tidak kolinear. Oleh karena uji prasyarat bahwa sebaran data keterampilan berpikir kritis dan kemampuan pemecahan masalah, varian antar model pembelajaran adalah homogen, matriks varian variabel terikat adalah sama, dan variabel keterampilan berpikir kritis dan kemampuan pemecahan masalah tidak kolinear, maka uji MANOVA satu jalur dapat dilanjutkan.

Pada penelitian ini diajukan tiga hipotesis. Pengujian hipotesis yang pertama digunakan MANOVA satu jalur. Hasil analisis disajikan pada Tabel 3.

Tabel 3. Rekapitulasi Hasil MANOVA Satu Jalur

\begin{tabular}{llrrrrc}
\hline Effect & Value & \multicolumn{1}{c}{ F } & Hypothesis df & Error df & Sig. \\
\hline \multirow{5}{*}{ Intercept } & Pillai's Trace & .968 & $1199.659^{\mathrm{a}}$ & 2.000 & 79.000 & .000 \\
& Wilks' Lambda & .032 & $1199.659^{\mathrm{a}}$ & 2.000 & 79.000 & .000 \\
& Hotelling's Trace & 30.371 & $1199.659^{\mathrm{a}}$ & 2.000 & 79.000 & .000 \\
& Roy's Largest Root & 30.371 & $1199.659^{\mathrm{a}}$ & 2.000 & 79.000 & .000 \\
\hline \multirow{3}{*}{ MODEL } & .660 & $76.528^{\mathrm{a}}$ & 2.000 & 79.000 & .000 \\
& Pillai's Trace & .340 & $76.528^{\mathrm{a}}$ & 2.000 & 79.000 & .000 \\
& Wilks' Lambda & 1.937 & $76.528^{\mathrm{a}}$ & 2.000 & 79.000 & .000 \\
& Hotelling's Trace & 1.937 & $76.528^{\mathrm{a}}$ & 2.000 & 79.000 & .000 \\
\hline
\end{tabular}

Berdasarkan ringkasan analisis MANOVA satu jalur yang disajikan pada Tabel 2, dapat diinterpretasikan bahwa taraf signifikansi untuk Pillai's Trace, Wilks' Lambda, Hotelling's Trace, 
dan Roy's Largest Root semuanya lebih kecil dari 0,05 , sehingga $\mathrm{H}_{0}$ ditolak. Jadi, terdapat perbedaan keterampilan berpikir kritis dan kemampuan pemecahan masalah antara kelompok siswa yang belajar dengan model pembelajaran STM dan model pembelajaran DI.

Pengujian hipotesis kedua dan ketiga dengan test of between-subjects effects. Rekapitulasi hasil test of between-subjects effects disajikan pada Tabel 4.

Tabel 4. Rekapitulasi Hasil Test of Between-Subjects Effects

\begin{tabular}{|c|c|c|c|c|c|c|}
\hline Sumber & $\begin{array}{l}\text { Variabel } \\
\text { Bebas }\end{array}$ & $\begin{array}{l}\text { Jumlah Kwadrat } \\
\text { Tipe III }\end{array}$ & $d b$ & $\begin{array}{l}\text { Rerata } \\
\text { Kwadrat }\end{array}$ & $\mathbf{F}$ & Sig. \\
\hline \multirow{2}{*}{ Korektif Model } & KBK & $.046^{\mathrm{a}}$ & 1 & .046 & 3.336 & .041 \\
\hline & KPM & $1.412^{\mathrm{b}}$ & 1 & 1.412 & 146.110 & .000 \\
\hline \multirow{2}{*}{ Intersep } & KBK & 7.148 & 1 & 7.148 & 514.293 & .000 \\
\hline & KPM & 16.587 & 1 & 16.587 & 1716.475 & .000 \\
\hline \multirow{2}{*}{ KELOMPOK } & KBK & .046 & 1 & .046 & 3.336 & .041 \\
\hline & KPM & 1.412 & 1 & 1.412 & 146.110 & .000 \\
\hline \multirow{2}{*}{ Kesalahan } & KBK & 1.112 & 80 & .014 & & \\
\hline & KPM & .773 & 80 & .010 & & \\
\hline \multirow{2}{*}{ Total } & KBK & 8.306 & 82 & & & \\
\hline & KPM & 18.772 & 82 & & & \\
\hline \multirow{2}{*}{ Total Koreksi } & KBK & 1.158 & 81 & & & \\
\hline & KPM & 2.185 & 81 & & & \\
\hline
\end{tabular}

Keterangan: KBK adalah keterampilan berpikir kritis dan KPM adalah kemampuan pemecahan masalah

Berdasarkan rekapitulasi hasil test of between-subjects effects, dapat diinterpretasikan bahwa pengaruh model pembelajaran terhadap keterampilan berpikir kritis, ditunjukkan dengan harga statistik $\mathrm{F}$ sebesar 3,336 dengan angka signifikansi 0,041. Angka signifikansi tersebut lebih kecil dari 0,05 , sehingga $\mathrm{H}_{0}$ ditolak. Jadi, terdapat perbedaan keterampilan berpikir kritis antara kelompok siswa yang belajar dengan model pembelajaran STM dan model pembelajaran DI.

Berdasarkan rekapitulasi hasil test of between-subjects effects, dapat diinterpretasikan bahwa pengaruh model pembelajaran terhadap kemampuan pemecahan masalah siswa, ditunjukkan dengan harga statistik $F$ sebesar 146,110 dengan angka signifikansi 0,000. Angka signifikansi tersebut lebih kecil dari 0,05 , sehingga $\mathrm{H}_{0}$ ditolak. Jadi, terdapat perbedaan kemampuan pemecahan masalah antara kelompok siswa yang belajar dengan model pembelajaran STM dan model pembelajaran DI.

Sebagai tindak lanjut dari pengujian hipotesis kedua dan ketiga, maka dilakukan analisis signifikansi perbedaan skor rata-rata keterampilan berpikir kritis dan kemampuan pemecahan masalah antar kelompok model pembelajaran dengan menggunakan metode Least Significant Difference (LSD), seperti disajikan pada Tabel 5.

Tabel 5. Analisis Signifikansi Perbedaan Skor Rata-Rata

\begin{tabular}{cccc}
\hline Variabel Terikat & $\boldsymbol{\Delta} \boldsymbol{\mu}=[\boldsymbol{\mu}($ MP.STM $)-\boldsymbol{\mu}($ MP.DI $)]$ & signifikan & LSD \\
\hline KBK & 0,058 & 0.011 & 0,052 \\
KPM & 0.262 & 0.000 & 0,044 \\
\hline
\end{tabular}

Berdasarkan Tabel 5 terlihat pada taraf signifikansi ( $\alpha$ ) sebesar 0,05 , perbedaan skor rata-rata keterampilan berpikir kritis kelompok siswa MP.STM dan MP.DI adalah $\Delta \mu=$ $[\mu($ MP.STM) - $\mu$ (MP.DI)] sebesar 0,058 dan angka signifikansi 0,011. Angka signifikansi tersebut lebih kecil dari 0,05 . Skor $\Delta \mu$ lebih besar daripada batas penolakan LSD. Jadi, skor rata-rata keterampilan berpikir kritis siswa kelompok MP.STM dan MP.DI berbeda lebih baik pada taraf signifikansi 0,05 . Perbedaan skor rata-rata kemampuan pemecahan masalah siswa MP.STM dan MP.DI adalah $\Delta \mu=[\mu$ (MP.STM) - $\mu$ (MP.DI)] sebesar 0,262 dan angka signifikansi 0,044 . Angka signifikansi tersebut lebih kecil dari 0,05 . Nilai $\Delta \mu$ lebih besar daripada penolakan LSD. Jadi, nilai rata-rata kemampuan pemecahan masalah siswa kelompok MP.STM dan MP.DI berbeda lebih baik pada taraf signifikansi 0,05. 
Berdasarkan analisis uji hipotesis terhadap ketiga hipotesis dalam penelitian ini, hasil uji hipotesis dapat diringkas sebagai berikut.

Pengujian hipotesis pertama, hipotesis nol ditolak dan hipotesis alternatif diterima. Ini berarti terdapat perbedaanketerampilan berpikir kritis dan kemampuan pemecahan masalah siswa yang dibelajarkan dengan MP.STM dan MP.DI. Hasil analisis multivariat menunjukkan skor statistik $\mathrm{F}$ yang diperoleh dari sumber pengaruh model pembelajaran terhadap keterampilan berpikir kritis dan kemampuan pemecahan masalah siswa adalah $F=76,528$ dengan angka signifikansi 0,000 . Skor statistik ini lebih kecil daripada taraf signifikansi 0,05 $(\mathrm{p}<0,05)$ dan memiliki makna bahwa terdapat perbedaan keterampilan berpikir kritis dan kemampuan pemecahan masalah siswa antara kelompok siswa yang belajar dengan model pembelajaran STM dan DI. Hal ini juga dapat dilihat dari perolehan skor gain untuk keterampilan berpikir kritis dengan MP.STM skor gain 0,32 (katagori sedang) dan MP.DI skor gain 0,27 (katagori rendah) Sedangkan kemampuan pemecahan masalah untuk MP.STM skor gain 0,58 (katagori sedang) dan MP.DI nilai skor gain 0,32 (katagori sedang)

Hasil penelitian ini sejalan dengan hasil penelitian yang dilakukan oleh Yager (1994) yang mendapatkan bahwa model pembelajaran STM terbukti lebih baik dalam meningkatkan hasil belajar siswa Hasil penelitian ini konsisten dengan penelitian yang dilakukan Burris \& Garton (2007) yang menunjukkan bahwa perbedaan perlakuan memberikan pengaruh terhadap keterampilan berpikir kritis dan pengetahuan siswa. Hal ini juga diperkuat oleh penelitian yang dilakukan Nurchayati (2012) yang menunjukkan bahwa terdapat perbedaan keterampilan berpikir kritis yang lebih baik antara kelompok siswa yang menggunakan MP.STM dibandingkan dengan MP.DI.

Terkait kemampuan pemecahan masalah, hasil penelitian yang dilakukan oleh oleh Suma (2006) yang meneliti pengaruh struktur kelompok dan tipe masalah terhadap kinerja pemecahan masalah siswa menemukan bahwa kinerja pemecahan siswa yang belajar pemecahan masalah dalam setting kelompok kooperatif lebih baik daripada siswa yang belajar pemecahan masalah dalam setting kelompok kompetitif baik untuk tipe permasalahan realistik maupun permasalahan akademik.

Berdasarkan hal tersebut, tampak bahwa hasil penelitian ini konsisten dengan hasil penelitian sebelumnya dan teori-teori yang ada. Adapun beberapa alasan yang dapat dijadikan dasar kelompok MP.STM lebih baik dalam pencapaian keterampilan berpikir kritis dan kemampuan pemecahan masalah siswa dibandingkan dengan kelompok MP.DI adalah sebagai berikut.

Seperti diketahui bahwa MP.STM dalam pembelajaran sains merupakan "perekat" yang mempersatukan sains, teknologi, dan masyarakat (Rustum Roy dalam Sadia, 2009). Melalui model pembelajaran STM, para siswa belajar sains dalam konteks pengalaman nyata, yang mencakup penerapan sains dan teknologi. Pengetahuan yang dibangun melalui model pembelajaran STM akan ada pada diri siswa sebagai copy situasi kehidupan nyata. Model sains teknologi masyarakat adalah penggunaan model dalam kegiatan pembelajaran dengan jalan melatih siswa menghadapi berbagai isu-isu yang berkembang dalam masyarakat yang berkaitan dengan sains dan teknologi untuk dipecahkan secara sendiri atau secara bersamasama, siswa melakukan pemecahan masalah yang disajikan dengan menggali informasi yang sebanyak-banyaknya, kemudian dianalisis dan dicari solusi dari permasalahan yang ada, dalam hal ini siswa dituntut untuk menggunakan keterampilan berpikir kritisnya sehingga siswa akan belajar lebih bermakna dan dapat mengembangkan pemikirannya jika siswa diberi kesempatan untuk bekerja, menemukan, dan mengkontruksi sendiri pengetahuannya.

Sedangkan pada model pembelajaran langsung diawali dengan penyajian materi pelajaran yang terkait oleh guru kepada siswa. Teori, konsep, ataupun prinsip-prinsip sains yang diharapkan dapat dikuasai oleh siswa dipaparkan terlebih dahulu di depan kelas oleh guru. Setelah itu, barulah siswa dihadapkan pada pertanyaan-pertanyaanan yang terkait dengan materi yang telah dipaparkan. Pertanyaan yang disampaikan kepada siswa hanyalah pertanyaan yang membutuhkan satu jawaban yang benar terkait materi yang telah disampaikan guru. Berdasarkan deskripsi landasan operasional teoretik tersebut, dapat dipahami bahwa MP. STM lebih unggul dibandingkan dengan MP.DI dalam pencapaian keterampilan berpikir kritis dan kemampuan pemecahan masalah.

Pengujian hipotesis kedua, hipotesis nol ditolak dan hipotesis alternatif diterima. Hasil uji MANOVA terhadap hipotesis penelitian II dengan menggunakan test of between-subjects effects menunjukkan nilai statistik $F$ sebesar 3,336 dengan signifikansi 0,041 . Ini berarti terdapat perbedaan keterampilan berpikir kritis siswa yang signifikan antara kelompok siswa yang dibelajarkan dengan MP.STM dan MP.DI. 
Beberapa alasan yang dapat dijadikan dasar bahwa kelompok MP.STM lebih baik dalam pencapaian keterampilan berpikir kritis dibandingkan dengan kelompok MP.DI adalah sebagai berikut.

Pada MP.STM terdapat empat fase pembelajaran, fase pertama yaitu invitation dimana siswa /guru mengungkapkan isu-isu atau masalah terkait dengan situasi kehidupan nyata siswa. Hal ini mengharuskan siswa berfikir untuk menganalisis isu tersebut. Dengan demikian ada interaksi antara guru dan siswa atau antara siswa dengan siswa lain. Proses interaksi ini menuntut seseorang untuk berfikir tentang ide-ide dan analisis yang akan dikemukakan atau cara mempertahankan pandangan tentang isu-isu tersebut, sehingga indikator keterampilan berpikir kritis yang dapat muncul dan dikembangkan dalam langkah ini adalah interpretasi dan analisis.

Pada fase Exploration, siswa mengidentifikasi pertanyaan-pertanyaan kristis/spesifik yang diperlukan untuk mengarahkan isu-isu yang dibahas pada materi pembelajaran. Fase eksplorasi memberikan dasar untuk memformulasikan hipotesis, mendesain penjelasan dan mengajukan pemecahan masalah pada fase selanjutnya. Indikator keterampilan berpikir kritis yang dapat dikembangkan dan dilatih pada tahapan ini adalah interpretasi, analisis, evaluasi, inferensi, dan eksplanasi. Penyelidikan dan aktivitas memecahkan masalah yang dilakukan pada tahap ini akan mampu melatih kemampuan siswa dalam memahami atau menginterpretasi data dan informasi yang diperoleh, menganalisis data hasil diskusi, memberikan argumen-argumen dalam kegiatan diskusi, mengambil keputusan atau memutuskan konsekuensi yang harus diambil dari informasi yang diperoleh terkait dengan solusi terhadap permasalahan.

Pada fase yang ketiga yaitu fase proposing explanations and solutions, siswa bersama kelompoknya menganalisis informasi yang telah dikumpulkan dari kegiatan eksperimen/studi pustaka kemudian mensintesis pemecahan masalah berdasarkan hasil analisanya. Pemecahan masalah yang diperoleh masing-masing kelompok dipresentasikan melalui kegiatan diskusi kelas sehingga setiap kelompok dapat membandingkan hasil yang mereka peroleh. Hal ini tentu juga dituntut menggunakan keterampilan berpikirnya untuk mengungkapkan atau menanggapi hasil pemecahan masalah dalam diskusi kelompok. Indikator keterampilan berpikir kritis yang dapat dilatih dan dikembangkan pada tahap ini adalah interpretasi, analisis, evaluasi, inferensi, dan eksplanasi. Pada tahap ini, siswa diberikan kesempatan untuk mengemukakan argumen, memberikan penjelasan, menyatakan hasil pemikiran yang disertai dengan bukti dan fakta, menganalisis berbagai penjelasan dan argumen melalui forum diskusi kelas, melakukan kegiatan diskusi dengan menguji dan menilai berbagai argumen, dan mampu memberikan kesimpulan berdasarkan data, informasi, serta argumen-argumen yang dikemukan dalam kegiatan diskusi.

Pada fase terakhir yaitu fase taking action, siswa mengaplikasikan konsep-konsep yang telah dipelajari pada permasalahan lain yang terkait dan guru memberi kesempatan kepada siswa untuk menyimpulkan seluruh kegiatan yang telah dilakukan. Indikator keterampilan berpikir kritis yang dapat dikembangkan adalah inferensi dan eksplanasi.

Dalam model pembelajaran langsung guru sangat dominan dan guru harus mendemonstrasikan pengetahuan atau keterampilan yang dilatihkan kepada siswa secara langkah demi langkah, sehingga kurang melatih keterampilan kritis siswa.

Pengujian hipotesis ketiga, hipotesis nol ditolak dan hipotesis alternatif diterima. Hasil uji MANOVA terhadap hipotesis penelitian III dengan menggunakan test of between-subjects effects menunjukkan nilai statistik $F$ sebesar 146,110 dengan signifikansi 0,000 . Ini berarti terdapat perbedaan kemampuan pemecahan masalah siswa yang signifikan antara kelompok siswa yang dibelajarkan dengan MP.STM dan MP.DI.

Beberapa alasan yang dapat dijadikan dasar bahwa kelompok MP.STM lebih baik dalam pencapaian kemampuan pemecahan masalah dibandingkan dengan kelompok MP.DI adalah sebagai berikut.

Pemecahan masalah adalah keterampilan dasar yang dibutuhkan oleh peserta didik saat ini, hal ini berarti kemampuan pemecahan masalah merupakan kemampuan seseorang untuk memecahkan suatu permasalahan yang dikaitkan dengan konsep-konsep yang diperoleh sebelumnya. Siswa akan memiliki kemampuan pemecahan masalah dengan baik jika diterapkan suatu model pembelajaran yang menekankan pada aktivitas kegiatan pemecahan masalah.

Pada MP. STM pada fase invitation dimana siswa /guru mengungkapkan isu-isu atau masalah terkait dengan situasi kehidupan nyata siswa, Indikator kemampuan masalah yang dikembangkan pada fase invitation adalah indikator mengidentifikasi masalah terkait isu yang 
telah diajukan oleh siswa/guru, siswa selanjutnya merumuskan dan menganalisis permasalahan yang terdapat di dalam isu-isu tersebut sesuai dengan indikator merumuskan (menganalisis) masalah.

Pada fase Exploration, siswa mengidentifikasi pertanyaan-pertanyaan kristis/spesifik yang diperlukan untuk mengarahkan isu-isu yang dibahas pada materi pembelajaran, Indikator yang dikembangkan pada fase ini adalah mengidentifikasi masalah dan menganalisis masalah terkait isu.

Pada fase yang ketiga yaitu fase proposing explanations and solutions, siswa bersama kelompoknya menganalisis informasi yang telah dikumpulkan dari kegiatan eksperimen/studi pustaka kemudian mensintesis pemecahan masalah berdasarkan hasil analisanya. Indikator yang dapat dikembangkan pada fase ini adalah menganalisis masalah dan menemukan alternatif-alternatif solusi terhadap permasalahan pada isu, indikator memilih alternatif solusi (terbaik) yang dapat dilakukan, indikator kelancaran memecahkan masalah dan kualitas hasil pemecahan masalah.

Pada fase terakhir yaitu fase taking action, siswa mengaplikasikan konsep-konsep yang telah dipelajari pada permasalahan lain yang terkait dan guru memberi kesempatan kepada siswa untuk menyimpulkan seluruh kegiatan yang telah dilakukan. Indikator yang dapat dikembangkan pada fase ini adalah kualitas hasil pemecahan masalah, karena pada fase taking action siswa diharapkan dapat memberikan kesimpulan berdasarkan hasil diskusi kelompok dengan baik dan benar.

\section{Simpulan dan Saran}

Berdasarkan hasil penelitian dan pembahasan, maka dapat diuraikan tiga simpulan yang merupakan jawaban terhadap tiga masalah yang diajukan dalam penelitian ini, yaitu: (1) Terdapat perbedaan keterampilan berpikir kritis dan kemampuan pemecahan masalah antara kelompok siswa yang belajar dengan MP. STM dalam pembelajaran biologi bermuatan karakter dengan kelompok siswa yang belajar dengan MP.DI. (2) Terdapat perbedaan keterampilan berpikir kritis antara kelompok siswa yang belajar dengan MP.STM dalam pembelajaran biologi bermuatan karakter dengan kelompok siswa yang belajar dengan model MP.DI (3) Terdapat perbedaan kemampuan pemecahan masalah antara kelompok siswa yang belajar dengan MP.STM dalam pembelajaran biologi bermuatan karakter dengan kelompok siswa yang belajar dengan MP.DI. Sebagai implikasi dari penelitian ini bahwa berdasarkan hasil penelitian menunjukkan bahwa model pembelajaran STM lebih tepat diterapkan dibandingkan dengan model pembelajaran DI dalam pencapaian keterampilan berpikir kritis dan kemampuan pemecahan masalah siswa. Model pembelajaran STM lebih menekankan pada pengalaman belajar siswa. Pengalaman dapat mengembangkan karakter siswa tanggung jawab, rasa ingin tahu, kerja sama, disiplin dan peduli lingkungan. Sebagai konsekuensinya, proses pembelajaran di sekolah sebaiknya didasarkan pada pengalaman siswa.

Berdasarkan hasil penelitian ini, maka dapat disampaikan saran hendaknya guru dapat menerapkan model pembelajaran sains teknologi masyarakat dalam pembelajaran biologi bermuatan karakter sebagai alternatif model pembelajaran berbasis kontruktivistik selama proses pembelajaran di kelas. Hal ini bertujuan untuk meningkatkan keterampilan berpikir kritis dan kemampuan pemecahan masalah siswa.

\section{Daftar Pustaka}

Depdiknas. 2006. Sosialisasi KTSP. CD -ROM. Jakarta: Ditjen PMPTK, Depdiknas

Dass, Pradeep M. 2005. Using a Science/Technology/Society Approach to Prepare ReformOriented Science Teachers: The Case of a Secondary Science Methods Course. Artikel. Issues in Teacher Education, 14(1), 95-108.

Delphi Team. 1990. The critical thingking skills test. California: The California Academic Press.

Johnson, E. B. 2002. Contextual Teaching and Learning: what it is and why it's here to stay. United States of America: Corwin Press, INC.

Nazir, M. 2003. Metode penelitian. Jakarta: Ghalia Indonesia. 
IVCEJ, Vol 1 No 1, Tahun 2018

Nurchayati. 2012. Pengaruh Model Pembelajaran Sains Teknologi Masyarakat Terhadap Kemampuan Berpikir Kritis dan Keterampilan Proses Sains Biologi Siswa SMA. Laporan Penelitian Tesis (tidak diterbitkan). UNDIKSHA

Paidi. 2008. Pengembangan Perangkat Pembelajaran dan Pengaruhnya terhadap Kemampuan Metakognitif, Pemecahan Masalah, dan Penguasaan Konsep Biologi. Jurnal Pendidikan Biologi UM Malang.Volume 1,Tahun I.

Sadia, I. W. 2008. Model Pembelajaran yang Efektif untuk Meningkatkan

Keterampilan Berpikir Kritis. Jurnal pendidikan dan Pengajaran Undiksha, 41(2): 219-237, April 2008.

Sadia, I W. 2009. Pendekatan Sains Teknologi Masyarakat dalam Pembelajaran Sains. Makalah. Disajikan pada Diklat Strategi Pembelajaran Inovatif Bagi Guru Fisika di Lingkungan Dinas Pendidikan Provinsi Bali Tanggal 22 s/d 27 Agustus 2009.

Sadia I W. 2011. Teori Belajar Konstrutivisme dan Implementasinya dalam Pembelajaran.Materi Kuliah Metodelogi Pembelajaran Sains S2 Program Pendidikan Sains.

Schafersman, S. D. 1991. An introduction to critical thinking. Tersedia pada http://www.freeinquary.com/critical-thinking.html.

Sugiyono. 2008. Metode Penelitian Pendidikan. Bandung: Alfabeta.

Suma, K. 2006. Pengaruh struktur kelompok dan tipe masalah terhadap kinerja pemecahan masalah siswa. Jurnal pendidikan dan pengajaran. Vol. 39. No. 1. 1-13.

Wikipedia. 2010. List of countries by human development index. Terdapat pada http://en.wikipedia.org/wiki/List_of_countries_by_Human_Development_Index. Diakses tanggal 10 Desember 2013.

Yager, Robert E. 1994. Assessment Results with the Science/ Technology/ Society Approach. Artikel. Tersedia pada: http://userpages.umbc.edu/ blunck/pdf/4.\%20publications/backup\%20publication\%20files/assessment\%20results\% 20with\%20the\%20sts/assessment\%20results\%20with\%20the\%20sts.pdf. Diakses tanggal 5 Nopember 2013.

Yamin, H. M. 2008. Paradigma pendidikan konstruktivistik. Jakarta: Gaung Persada Press. 